\title{
Fausto Curi, Il corpo di Dafne. Variazioni e metamorfosi del soggetto nella poesia moderna
}

\section{Mario Richter}

\section{(2) OpenEdition}

1 Journals

\section{Edizione digitale}

URL: http://journals.openedition.org/studifrancesi/3809

DOI: 10.4000/studifrancesi.3809

ISSN: 2421-5856

\section{Editore}

Rosenberg \& Sellier

\section{Edizione cartacea}

Data di pubblicazione: 1 décembre 2012

Paginazione: 596

ISSN: 0039-2944

\section{Notizia bibliografica digitale}

Mario Richter, «Fausto Curi, Il corpo di Dafne. Variazioni e metamorfosi del soggetto nella poesia

moderna», Studi Francesi [Online], 168 (LVI | III) | 2012, online dal 30 novembre 2015, consultato il 07 mars 2021. URL: http://journals.openedition.org/studifrancesi/3809 ; DOI: https://doi.org/10.4000/ studifrancesi.3809

Questo documento è stato generato automaticamente il 7 mars 2021.

\section{(c) (1)}

Studi Francesi è distribuita con Licenza Creative Commons Attribuzione - Non commerciale - Non opere derivate 4.0 Internazionale. 
Fausto Curi, Il corpo di Dafne. Variazioni e metamorfosi del soggetto nella poesia moderna

Mario Richter 


\section{NOTIZIA}

FAUSTO CURI, Il corpo di Dafne. Variazioni e metamorfosi del soggetto nella poesia moderna, Milano-Udine, Mimesis Edizioni, 2011, pp. 329.

Sulla base della constatazione che «quanto più la poesia avanza nel tempo fino a diventare quella che approssimativamente possiamo chiamare 'poesia moderna', tanto più le singole poetiche e le singole concezioni del soggetto si differenziano, fino a giungere a un punto di massima distanza dalla classicità» (p. 22), Fausto Curi si è impegnato a studiare l'evoluzione e i mutamenti del soggetto o dell' io nella poesia dell'età moderna, dall'Ottocento al Novecento. Ne diamo informazione in questa sezione perché l'A., che appunto indaga diacronicamente, a cominciare dal mondo antico, un tema tanto appassionante (il carattere unitario del soggetto entra in crisi soprattutto con Marx, Nietzsche e Freud), compie numerose incursioni in aspetti particolarmente significativi della poesia francese. Il lettore potrà in tal modo trovare puntuali e interessanti rilievi su Baudelaire («Il nuovo e il male. Baudelaire e il dandy»; «Baudelaire, il soggetto indemoniato»), su Lautréamont («Lautréamont, poesia personale e poesia impersonale») e naturalmente su Rimbaud («Rimbaud, il soggetto è un altro») nonché su Mallarmé («Mallarmé, la sparizione del soggetto»). Il libro, che ha un carattere spiccatamente interdisciplinare e si segnala per la sua vivacità oltre che per la sua attenzione all'attualità, costituisce un apporto di particolare rilievo, anche grazie alla ricchezza e al rigore dell'informazione, per chiunque desideri addentrarsi nei rapporti complessi e suggestivi della cultura europea considerata nel suo insieme e nelle singole numerose personalità che la caratterizzano. 